\title{
Research on the Path of Building Audit Team in Colleges and Universities in the New Period
}

\author{
Wenlei CHEN \\ Nanjing University of Finance and Economics \\ Nanjing, China
}

\begin{abstract}
Over the past 30 years, China's audit institutions have maintained the financial and economic order of the country and effectively guaranteed the healthy development of the economy and society, also college auditing has played an important role in the economic activities of higher education. Based on analyzing the necessity of the construction of audit team in colleges and universities, this paper finds out the problems existing in the construction of audit team in colleges and universities. In order to provide enlightenment for standardizing the economic activities of colleges and universities and enhance the quality of education in colleges and universities, this paper explores the path of improving ability of auditing team in colleges and universities from the following aspects: strengthening the political and ideological construction of audit staff in colleges and universities, improving the management system of audit work in colleges and universities, paying attention to the training of audit staff in colleges and universities, and perfecting the talent incentive mechanism of audit work and promoting the auditing information in colleges and universities.
\end{abstract}

Keywords-Audit; Internal Control; Team Building; Path

\section{INTRODUCTION}

On May 23, 2018, the Central Audit Committee held its first meeting. General Secretary $\mathrm{Xi}$ Jinping delivered an important speech. He emphasized the importance of auditing in improving the efficiency of financial funds, safeguarding national economic security and promoting the construction of clean and honest party conduct. He called on auditing institutions to strengthen their own construction, establishing themselves in the spirit of auditing, constructing a business with innovation and norms, and building up trust with self-construction. The "establishing”, “constructing” and "building" mentioned above are not only the political requirement of "earnestly fulfilling the political responsibility of governing the Party by all levels of Party organizations in audit institutions", but also the quality requirement of building a professional audit cadre team of "firm belief, professional proficiency, pragmatic style, honesty and integrity”. College auditing plays an important role in ensuring the standardization and orderliness of educational economic activities and promoting the scientific development of higher education, which points out the direction for the construction of college auditing team and the improvement of its ability in the new period. In order to give full play to the functions of audit institutions and explore the mechanism of innovative development of internal audit in colleges and universities, we have to think deeply about the following problems: what is the

This work is supported by two grants from Jiangsu Provincial philosophy and social science. (Grant No. 2018SJA0237), and NUFE (Grant No.DJ201931) current situation of the construction of audit team in colleges and universities in the new period? Why is it necessary to improve audit team construction and capacity in colleges and universities? What are the problems existing? How should colleges and universities carry out audit team training to adapt to the new situation?

We first sort the existing literature and consider the current situation of college auditing team construction in the new era. Then this paper systematically analyses the necessity of college auditing team construction in the new era, finds out the problems existing in the process of college auditing team construction, and puts forward specific measures and strategies to enhance the ability of audit team, hoping to provide new enlightenment and policy suggestion for college auditing team construction.

\section{THE NECESSITY OF STRENGTHENING THE CONSTRUCTION OF AUDIT TEAM IN COLLEGES AND UNIVERSITIES}

For a long time, the audit work in colleges and universities has escorted the reform and development of education, played an important role in improving the efficiency of the use of educational funds and promoting the construction of party conduct and clean government in colleges and universities. The high quality and high efficiency of audit work cannot implement without high-quality audit team. Therefore, it is of great significance to strengthen the construction of audit team in colleges and universities.

\section{A. Guarantee the Rational Utilization of Economic Resources in Colleges and Universities}

Unlike the operation mode of enterprises, colleges and universities are not for the purpose of making profits. Most colleges and universities in China are public institutions set up by government departments using state-owned assets. The founding, scientific research and teaching funds of colleges and universities mostly come from government financial appropriations and a small part from social donations. In terms of operational performance evaluation, universities are also different from enterprises that cannot measure by financial management concepts such as profit maximization or shareholder equity maximization. Namely, they cannot systematically evaluate performance from the aspects of financing ability, debt-paying and operating ability, compared with enterprises. Based on the particularity of university system, in order to ensure the effective development of educational economic activities, it is necessary for Chinese 
universities to build professional audit teams to improve the rational use of economic resources.

\section{B. Improving College Audit Supervision System}

The supervision system of college audit mainly contains internal audit and external audit. External auditing mainly work through the way of national auditing, that is, the government supervises and audits the financial revenue and expenditure of colleges and universities by means of spot checking according to establish specially auditing departments. Although external audit could play a certain role in supervision and review of university's economic activities, its supervision mode is from the macro perspective, and cannot ensure that supervision and inspection implement in every unit or link. There are still certain risks in university's financial operation. In order to make up for the shortcomings of external audit, it is an important way to evaluate and improve university risk management and control the effectiveness of university governance process to build university audit team and enhance the ability of audit team. Therefore, while relying on government accounting supervision, colleges and universities should use high-quality audit team to implement independent audit supervision, and play its role in strengthening accounting control, improving the quality of accounting information and safeguarding the economic benefits of colleges and universities, to improve the audit supervision system of colleges and universities.

\section{Reducing the Agency Cost of Colleges and Universities}

The conflict of interest between investors and operators due to information asymmetry is the kind of principal-agent problem. As investors, there are great differences in investment forms and purposes between universities and enterprises. In the process of financial management of colleges and universities, the expenditure on investment and construction and the funds for maintaining normal operation of colleges and universities all come from the financial allocation of the state. The agents of colleges and universities are principals and other managers with relevant management experience. In the process of management, university agents may also have acts of agency that are against the interests of the state and conducive to their own development. Therefore, in order to restrain the agency behavior of university managers and provide them with reliable basis for making correct decisions, it is necessary for universities to establish an audit team with outstanding ability to reduce agency costs.

\section{PROBLEMS EXISTING IN THE CONSTRUCTION OF AUdIT TEAM IN COLLEGES AND UNIVERSITIES}

With the deepening of educational and economic activities in colleges and universities, the importance of audit work has become more and more prominent, and the requirements for the ability of audit team have become higher and higher. In general, the internal audit institutions in colleges and universities in China are well established and have some qualified internal audit staff, but there are still some problems in the construction of the audit team.

\section{A. Attention to the Importance of Audit Work is Not High}

Although colleges and universities mainly focus on teaching work, internal audit work is becoming more and more important with the increasing enrollment scale and daily economic activities becoming more and more complex. On one hand, it can supervise the economic and administrative responsibilities of all the economic responsible persons in colleges and universities. On the other hand, it can expose the problems existing in violation of law and discipline, fraud for selfish ends, loss and waste, and management, to achieve the purpose of strengthening restraint and serious school rules and regulations to strengthen the management of colleges and universities. However, nowadays, the concept of auditing in colleges and universities is backward which emphasizes the function of supervision but neglect the function of service. Universities generally do not pay enough attention to the internal audit work, therefore neglect the construction of audit team.

\section{B. The Professional Quality of Auditors Needed Improvement}

In the new era, if we want to do college auditing well, we must pay attention to the improvement of professional quality and moral level of auditors. In addition to understand relevant laws and regulations, master relevant accounting, management, auditing and other professional knowledge, auditors should also maintain good moral literacy and independence, be good at communicating and grasping basic working skills. Nowadays, although the political and ideological quality of auditors constantly mentioned by the academic circles, many colleges and universities lack of effective and operational education methods, and the overall quality of auditors is uneven. Besides, the rapid development and wide application of computers and networks have brought new problems and challenges to the work of auditors, requiring auditors to be compound talents with knowledge of management and information technology.

\section{Modern Audit Technology and Method is Backward}

With the popularity of computers and the internet, automated office has replaced the traditional audit mode. Most colleges and universities often purchase audit work software from outside market. This kind of software cannot adapt to the specific situation of our school, and needs modified operation by relevant audit institutions, which require auditors not only to master the relevant professional knowledge, but also to master the relevant knowledge of computer software development. However, most of the auditors' majors in colleges and universities are finance and accounting, lacking of the ability to make use of information technology. The veteran comrades of audit departments in colleges and universities often do not understand the information of audit work and are unwilling to receive training of relevant knowledge, which greatly reduces the efficiency of audit work in colleges and universities.

\section{Lack of Independence of Internal Audit in Colleges and Universities}

Relevant data survey shows that: in the universities directly under the ministry of education, there are few independent internal audit institutions, less than half of which are set up independently. The proportion of local undergraduate colleges and higher vocational colleges is less, and even if they are set up, the institutions are imperfect, with fewer auditors. Because 
of the unreasonable setting of audit institutions, these audit institutions often lack of independence, which greatly affects the effect of college auditing. In addition, at the present stage, the audit of economic responsibility of leading cadres in colleges and universities in our country is mainly outgoing audit, short of audit during their tenure, which greatly reduces the effect of audit and makes it difficult to exert the supervision function of audit.

\section{APPROACHES TO STRENGTHEN THE CONSTRUCTION OF AUDIT TEAM IN COLLEGES AND UNIVERSITIES}

In order to solve the problems existing in the above-mentioned auditing team in colleges and universities and build a more advanced auditing team, we should notice the following two things. On one hand, relevant leaders need to attach great importance to the internal auditing work in colleges and universities. On the other hand, the auditing department should pay close attention to the development trend of the auditing work in colleges and universities, give full support to the study and training of auditors, and constantly improve their abilities and qualities.

\section{A. Strengthening the Political and Ideological Construction of Auditors in Colleges and Universities}

First of all, we should strengthen the political literacy and ideological construction of auditors in colleges and universities, help them establish correct political orientation, correct outlook on life, world outlook and values, and improve the ideological awareness of auditors, so as to ensure the independence of auditors and make the audit conclusions more fairer and more credible. Secondly, we should attach importance to the moral inspection and cultivation of auditors, adhere to the principle of "both moral and talent, taking moral as the first" and absorb excellent talents with correct thinking and professional skills into the auditing team. At the same time, we should strengthen the cultivation of moral quality and auditing culture, and improve the ability of auditing cadres to resist corruption and prevent corruption. Secondly, we should attach importance to the moral inspection and cultivation of auditors, adhere to the principle of "both moral and talent, taking moral as the first" and absorb excellent talents with correct thinking and professional skills into the auditing team. At the same time, we should strengthen the cultivation of moral quality and auditing culture, and improve the ability of auditing cadres to resist corruption and prevent corruption. Finally, the work results of auditors in colleges and universities should actively accept the supervision of the masses. On one hand, relevant audit reports should make public for the masses in time. On the other hand, internal supervision should be strengthened and internal auditors with imprecise working attitude and irregularities should be detected as soon as possible, to ensure the quality of the audit team.

\section{B. Improving and Perfecting the Management System of Auditing Work in Colleges and Universities}

In order to play the role of internal audit effectively in colleges and universities, it is necessary to establish an independent audit department, increase the training of audit team, and ensure the fairness of audit conclusions. It is not only necessary to stipulate detailed audit workflow and clear job responsibilities, including the acceptance of audit business, the formulation of audit plan, communication with auditees, the development of audit work, the publication of final audit report and the filing of related audit manuscripts. We should also make annual audit plans and make detailed audit plans independently according to the specific conditions of different colleges and departments, instead of waiting passively for the instructions of superior leaders. What is more, we also need to establish audit quality inspection and reward and punishment system, implement audit responsibility system, reward those who are loyal to their duties. Last, we should abide by discipline and law, and complete tasks on time, punishes those who violate laws and discipline and cause losses, and make clear rewards and punishments, to improve the work consciousness and enthusiasm of auditors.

\section{Focus on the Education and Training of Auditors in Colleges and Universities}

In the information age, the speed of knowledge updating become faster and faster with the economic environment is becoming more and more complex. It is necessary to enhance the work of training auditors to adapt to the constantly updated audit environment of audit technology. Firstly, it is necessary to establish professional access standards for auditors in colleges and universities. According to the relevant provisions of the state, practitioners are required to pass qualification examinations and complete registration certification to ensure their professional qualifications and professional qualities. Secondly, we should improve the recruitment threshold of audit staff in colleges and universities, and strictly control the ideological and moral, educational background, profession and ability of the employees. Thirdly, colleges and universities should attach importance to improving the ability of audit staff. On the premise of ensuring that auditors attend at least one continuing education and training every year, auditors should be encouraged to attend professional academic conferences, lectures and seminars to keep abreast of the academic trends of audit profession in a timely manner. At the same time, we should strengthen the communicate and exchange with auditing departments of other colleges and universities to learn advanced experience and improve the professional quality and work efficiency of college auditing staff.

\section{Perfecting the Talent Incentive Mechanism of Audit Work}

Establishing and perfecting a scientific and reasonable incentive mechanism for auditors is an effective means to mobilize auditors' enthusiasm, stimulate their working potential and improve their working efficiency. The incentive mechanism mainly includes the annual appraisal and evaluation system, the selection, promotion and motivation mechanism of audit talents. To give full play to the role of incentives, we need to do a good job in the following aspects: firstly, we should increase audit office funds and lay a good material foundation for the training of auditors, the improvement of audit efficiency and the exertion of supervision functions. Secondly, it is necessary to increase the introduction of audit talents, and comprehensively investigate their ideological quality, professional technology, audit level and the ability to use new media, and select excellent talents with both ability and morality to enrich the audit team. Thirdly, we should establish and improve the evaluation mechanism of 
audit work. According to the results of performance and competence assessment, we should reward and reuse outstanding staff members. At the same time, we should pay attention to the training of young audit staff cadres, mobilize the enthusiasm of auditors, create a good working atmosphere, and improve the overall performance of the entire audit team.

\section{E. Promoting the Information of Auditing Work in Colleges and Universities}

With the development of new media technology, auditing is becoming more and more standardized and intelligent. Firstly, in order to improve the level and efficiency of internal auditing, new requirements put forward for the work of auditors. Secondly, it urges auditors to master new media technology while doing their job well, and strive to develop a unified network platform for college auditing, to realize information sharing and transmission between audit departments and departments (including finance, logistics, personnel, etc.). Finally, we develop the relevant audit experience sharing information base, such as the establishment of document base database, case database and template database, to provide a reference for the work of college auditors.

\section{V.CONCLUSION}

In recent years, with the enlargement of the enrollment scale of higher education, the internal economic activities of colleges and universities have increased substantially, which puts forward higher requirements for the internal audit work of colleges and universities. At present, there are shortcomings in the management system, professional quality and auditing means of the auditing team in colleges and universities. In order to improve the efficiency and level of audit work in colleges and universities, it is urgent to improve the quality of audit team in colleges and universities. This study analyzed the necessity and existing problems of improving the ability of audit team in colleges and universities. Moreover, found out the ways to improve the ability of audit team, namely strengthen the political and ideological construction of audit staff in colleges and universities, pay attention to the training of audit staff in colleges and universities, improve the talent incentive mechanism of audit work, and promote the information of audit work in colleges and universities. Only when the audit team is well-constructed can the audit work be carried out smoothly, the development of various economic activities in colleges and universities be guaranteed, and ultimately the continuous development of higher education can be promoted.

\section{REFERENCES}

[1] Xiong Ying. How to correct the misunderstanding of party building work in audit institutions [J]. Auditing and Finance, 2019 (4).

[2] Zeng Haimei. Some thoughts on strengthening the construction of internal audit team in colleges and universities [J]. Journal of Sichuan Institute of Education, 2009, 25 (12): 11-13.

[3] Jia Guifen. Brief analysis on the problems and countermeasures of internal audit work in Chinese universities [J]. Journal of Liaoning Radio and TV University, 2010 (2): 72-73.

[4] Anna. Research on the Ideas of standardization construction and audit team construction of economic responsibility audit in colleges and universities [J]. China Township Enterprises Accounting, 2016 (1): 160-161.

[5] Miao Yaling, Zhao Jinzhuo and Zhao Wanhong. Talking about the ways to strengthen the construction of the internal audit team in colleges and universities [J]. Modern Economic Information, 2012 (7): 181.

[6] Huang Ming. On the construction of professional institution of the internal audit team in colleges and universities [J]. Communication of Finance and Accounting, 2014 (31): 96-97. 